\title{
MÉXICO E BRASIL: DOIS EXTREMOS DE UMA IDÉIA
}

\author{
Daniel Antiquera \\ Professor e Pesquisador da Universidade Estadual de Londrina, \\ Mestrando em Relações Internacionais pelo \\ Programa San Tiago Dantas- SP (Unesp, Unicamp e PUC-SP) \\ E-mail:dantiquera@uel.br
}

\section{RESUMO}

O artigo questiona o real peso que a idéia de América Latina teve e tem para os Estados que a compõe, mostrando que o sentido de unidade provém mais da relação de dependência do que de um projeto próprio. Para isso, escolheu-se analisar, além das tentativas regionais de integração, a evolução das políticas externas de México e Brasil, tentando identificar possíveis tendências (e dificuldades) de formulação de um projeto conjunto. A escolha desses países deve-se ao fato de representarem extremos dessa parte do continente americano. $\mathrm{O}$ estudo revela que a América Latina, como projeto político, sempre esteve mais distante da realidade do que os discursos possam aparentar. E a partir da década de 1990 a expressão ainda se tornou mais abstrata e fraca.

Palavras-Chave: América Latina. Políticas externas.

\begin{abstract}
This article questions the real strength Latin America had and has had in the formation of its States and shows that the sense of unity is more a consequence of dependence than a project of its own. It analyzes the regional attempts of integration, the evolution of external politics in Mexico and Brazil and it attempts to identify likely trends (and difficulties) for the formulation of a joint project. The choice upon these two countries is due to the fact that they represent the extremes of this American continent. This study reveals that Latin America, as a political project, has always been more distant from reality than the discourses may show. Such account has become even more abstract and superficial from the decade of 1990 on.

Key-words: Latin America, Foreign Affairs.
\end{abstract}

\section{Introdução}

Tanto na literatura acadêmica quanto nos discursos de atores políticos e sociais ${ }^{1}$ é bastante comum a utilização da expressão "América Latina". Claramente o termo constitui uma idéia consolidada. Resta, no entanto, que

\footnotetext{
${ }^{1}$ A referência em separado a acadêmicos, atores políticos e sociais não se fundamenta em qualquer concepção teórica ou opção metodológica. Pelo contrário, não se ignora que freqüentemente não existem limites a separar claramente uns dos outros (que muitas vezes exercem ao mesmo tempo os três papéis). No entanto, a opção por essa denominação serve apenas para deixar explícito que em diferentes campos de linguagem é comum a utilização da expressão "América Latina".
} 
nos perguntemos a qual realidade tal idéia nos remete.

Este trabalho pretende verificar qual a concretude da idéia da América Latina. Para isso, escolheu-se olhar a posição histórica de dois países, que representam, também geograficamente, os extremos da idéia da América Latina. Em outras palavras, a proposta é de traçar um perfil histórico da política externa do Brasil e do México, para identificar se houve realmente um projeto político que desse corpo à idéia em discussão, e entender as dificuldades correspondentes.

Em outras palavras, seria mais fácil juntar dados comparativos que indicassem semelhanças populacionais, sociais, econômicas ou mesmo políticas, que fazem a América Latina aparecer como unidade, inclusive com tendência à solidariedade e cooperação mútua decorrentes das semelhanças retratadas por aqueles dados. É preciso buscar os motivos por que os países latino americanos, ainda que tenham muitas coisas em comum, nunca conseguiram articular de fato um projeto consistente e eficiente de aumentar sua expressão no cenário mundial e, internamente, não conseguiram proporcionar a suas populações níveis aceitáveis de bem estar e distribuição de riquezas.

Talvez a maior contribuição que um estudo possa dar seja justamente indicar obstáculos que não aparecem na aclamação de um integracionismo superficial. E, a partir dessa indicação, apontar, ainda que imprecisamente, para direções diversas das que vêm sendo tomadas ao longo dos últimos séculos.

O objetivo maior é contribuir, ainda que de forma ínfima, ao exercício nunca estéril de repensar o continente latino americano, para não se conformar com sua situação indigna de orgulho.

\section{América Latina: o Problema}

O primeiro problema que surge da preocupação com a integração latino americana é a própria dificuldade de se caracterizar o que seja a América Latina e, mais, se é possível encontrar uma unidade expressa por esse nome. A questão não é muito discutida, e as referências à região são feitas sem o questionamento necessário para que o conceito tenha alguma concretude, ou seja, para que o nome expresse realmente alguma realidade. Um dos principais historiadores da região, Donghi (1997, p.7) adverte antes de iniciar sua obra, ainda no prefácio:

A própria unidade da América Latina é problemática; a extrema variedade da realidade latino americana é o que primeiro salta a vista do observador estrangeiro. Não foi por acaso que Lucien Lebvre intitulou o volume dedicado pelos Annales 
ao Continente de A travers les Amériques Latines [...] e, tal como para a América Latina em seu conjunto, o plural parece se impor, contra o uso gramatical, para refletir contrastes desconcertantes, até mesmo em países relativamente pequenos [...].

A história da região é a história da dominação por centros de poder mundial. Primeiro, pela península ibérica, que já registrou de forma contundente a primeira grande divisão: entre o império português e o império espanhol. Não se pode menosprezar a importância dessa distinção, que traz até os dias presentes um significativo empecilho para a aproximação: alíngua ${ }^{2}$.

Mas não foi apenas a variação lingüística que separou a América de colonização ibérica em duas. A luta entre Portugal e Espanha pela hegemonia sobre o novo continente também suscitou rivalidades históricas, como aquelas nascidas da região platina e da região amazônica. Mesmo do ponto de vista econômico as colônias tiveram funções diversas, visto que o Brasil não satisfez, a princípio, a ganância por metais preciosos que motivou as grandes navegações. A independência não amenizou a situação, posto que o sistema político e econômico adotado pelos novos países também criaram verdadeiras fronteiras, fontes de antipatia recíproca. O Brasil monárquico e escravista, oposto ao republicanismo americano, sempre foi alvo de desconfiança.

O México, por exemplo, ao contrário do Brasil, desde os primeiros anos de independência mostra aversão aos princípios monárquicos. Antes de conquistar sua autonomia política, houve duas revoltas populares, violentamente reprimidas, com programas que abrangiam reforma agrária e abolição da escravidão, entre outros. A independência foi feita, em 1821, pelos conservadores que instauraram a monarquia do imperador Itúrbide, que acaba numa guerra civil iniciada pelos liberais em 1854, chamada Guerra das Reformas. Depois da ascensão e queda de dois presidentes, num período em que foram suspensos pagamentos de dívidas internacionais, a França de Napoleão III intervém no México e dá o poder ao imperador Maximiliano. Mas este é derrubado e fuzilado pelas forças do ex-presidente Benito Juarez, numa segunda guerra de independência. As reformas foram concretizadas e

\footnotetext{
${ }^{2}$ Falando sobre a ignorância mútua entre a América hispânica e a portuguesa, Nestor dos Santos Lima (1978, p. 15), à época embaixador brasileiro na Venezuela, lembra da importância da língua como fator de distanciamento: "[...] el silencio sobre la presencia brasileña en el continente, por irreal que parezca, es la más tranquilizadora de las actitudes, para quien concibe una América llamada latina, que habla una sola lengua, y que actúa y piensa conforme al código cultural traído al continente por los conquistadores españoles." A idéia fica clara, no século XIX, em discursos de Simon Bolivar (1992, p.72): "É uma idéia grandiosa pretender formar de todo o Novo Mundo uma só nação com um único vínculo que ligue suas partes entre si e com o todo. Por ter uma só origem e língua, mesmos costumes e única religião, deveria ter um único governo que confederasse os diferentes Estados que venham a formar-se"
} 
o Estado passou a investir fortemente em educação primária.

O Brasil teve uma independência sem maiores convulsões, que deita raízes na vinda da família real portuguesa ao país, em 1808, seguida pela abertura dos portos e a elevação à condição de Reino Unido. Sua efetivação se dá pela iniciativa do próprio herdeiro do trono português, sem qualquer participação popular e sem que, de fato, implicasse uma ruptura no projeto português de consolidação das fronteiras no território americano. Essa continuidade de projetos, e a manutenção da forma monárquica ajudam a explicar o êxito do Brasil em manter-se unido e íntegro territorialmente, diferente do processo de fragmentação da América Hispânica.

Não se despreze a importância dessas diferenças genéticas para as relações internacionais na América Latina. O Brasil era considerado fruto excêntrico do Novo Continente, visto com antipatia e observado com desdém. Assim é que a política externa do Brasil começa com o isolamento, chamado "Esplêndido Isolamento" por Euclides da Cunha. Sua relação com os vizinhos hispânicos pode ser exemplificada pelo reconhecimento precipitado do governo de Maximiliano, em 1862, no México, e pela Guerra do Paraguai iniciada em 1865.

A marginalização do Brasil fica evidente no momento do primeiro impulso integracionista, fruto do esforço e do idealismo de Simon Bolívar. Em 1815, em plena luta pela independência, o "Libertador" já sonha com a unificação entre os novos países:

Desejo, mais do que ninguém, ver formar-se na América a maior nação do mundo, menos por sua extensão e riquezas que por sua liberdade e glória. [...] Direi ao senhor o que pode nos tornar capazes de expulsar os espanhóis e de fundar um governo livre: é a união, sem dúvida; mas essa união não nos chegará por milagres divinos, e sim por efeitos sensíveis e esforços bem dirigidos. (BOLÍVAR, 1992, p. 67, 74).

É preciso se ressaltar, no entanto, que o Brasil estava completamente excluído das análises de Bolívar, assim como os EUA. Não há qualquer referência à ex-colônia portuguesa, mas apenas, e de forma bastante agressiva, à monarquia. O México, ao contrário, tinha posição de destaque nos planos de Bolívar (1992, p.67): "A metrópole, por exemplo, seria o México, a única com capacidade para isso, por seu poder intrínseco, sem o qual não há metrópole". O projeto de uma confederação baseado em três federações que reunissem os países que lutavam contra a Espanha não vingou. Em 1824 foi convocado o Congresso do Panamá, numa tentativa frustrada de se evitar a fragmentação do território que antes pertencera à Espanha.

No momento do Congresso do Panamá, a dominação ibérica do Novo 
Continente já dá sinais de esgotamento, e a região passa a ser objeto de disputa de outras nações, principalmente a Grã Bretanha, que apóia as lutas de independência e reconhece os novos países. Ainda que na primeira metade do século XIX a Grã Bretanha seja o país com influência preponderante na América de colonização ibérica, outra potência começa a considerar a região em seus planos estratégicos: os EUA, que só vão consolidar sua hegemonia no continente no fim do século XIX, mas desde a década de 20 já formulam a política externa para o Continente. A doutrina de Bolívar, nesse contexto, pode ser vista como o primeiro sinal de oposição às pretensões de preponderância dos EUA sobre a América, resumidas na doutrina Monroe ${ }^{3}$. O México, ponto de contato da América Latina com os EUA, ilustra especialmente essa oposição, porque lá a relação não foi apenas diplomática.

Em 1835 o México perde o Texas, que se torna independente, numa rebelião dos colonos vindos dos EUA. No afã de reconquistar o território, o conservador General Santa Ana, então presidente, declara guerra, que acaba envolvendo, mais tarde os EUA (1845-1848). Os resultados dessa guerra são trágicos para o México, que perdeu 50\% de seu território, e teve que indenizar os colonos com US\$ 3 milhões, além de um tributo de guerra aos EUA de US\$ 15 milhões. Sem contar os recursos naturais daqueles territórios, como ouro e petróleo. Talvez o melhor cenário para o México, teria sido aceitar a independência do Texas, que funcionaria como Estado- Tampão ${ }^{4}$, como defendia o líder do partido conservador mexicano, Lucas Alamán. Ele imaginava que um Estado independente, sob proteção da Grã Bretanha, poderia conter a tendência de expansão dos EUA (DONGHI, 1997, p.107).

Como se vê, os primeiros contatos mais intensos dos EUA com a América Latina não foram mediados pela cordialidade, e isso reforçou a ineficácia da idéia do panamericanismo na América Latina. O Brasil, mais uma vez em sentido inverso de seus vizinhos, desde a metade do século XIX passa a aproximar-se mais dos EUA que da Grã Bretanha, processo que culmina com a linha diplomática do Barão do Rio Branco, ministro das relações exteriores de 1902 a 1912.

É fundamental que se perceba a relação dos países latino americanos com as potências mundiais, pois a referência à região sempre é feita como um

\footnotetext{
${ }^{3}$ A Doutrina Monroe (nascida em 1823, da mensagem do presidente James Monroe ao Congresso) foi, ao mesmo tempo, uma forma de afastar a influência européia do Novo Continente, e a primeira manifestação das intenções norte americanas de submeter a América à sua direção e aos seus projetos. Essa doutrina, como aponta Magnoli (1997, p.190-192) é a raiz da idéia de panamericanismo.

${ }^{4} \mathrm{O}$ conceito de Estado- Tampão é bastante conhecido dos geopolíticos, que assim entendem um território menor com função de evitar o confronto entre dois Estados maiores, justamente por estar entre eles.
} 
bloco de países subdesenvolvidos ou em desenvolvimento, em contraposição ao grupo de países desenvolvidos. De certa forma, então, sempre há pelo menos dois projetos mais ou menos conflitantes: aquele das grandes potências, que vêem a região como zona privilegiada de acumulação do capital e de realização de um comércio exterior superávitário, e os projetos de integração, que visam reunir forças, para alcançar um maior poder de barganha nas negociações internacionais.

Quando se pensa assim, surge mais um obstáculo, a princípio aparentando ser irrelevante, à consolidação de fato da América Latina. Um problema geográfico que se percebe na frase de Ferreira (1990, p.55): "A Geografia condenou a América Latina a estar noHemisfério Sul e a ser, por isso mesmo, permanentemente, objeto da história alheia”. Como se vê, existe uma disputa entre duas fronteiras- o Rio Grande, que separa os EUA da América Latina, e a linha do Equador, que coloca o México no Hemisfério Norte, mais próximo dos vizinhos ricos que dos pobres. Resta saber qual das duas fronteiras marcará mais intensamente suas divisões, e dessa disputa (simbólica, é verdade) resultarão as possibilidades de que a integração Latino Americana seja algo mais que discursos de embaixadores para platéias de vizinhos estrangeiros.

Por fim, é preciso não esquecer que mesmo supondo um isolamento da América Latina com relação ao mundo, a aproximação entre seus componentes não se torna natural. Além dos fatores históricos vistos neste capítulo, guerras travadas entre os próprios vizinhos, como a Guerra do Pacífico, a Guerra do Paraguai, e, mais recentemente, a Guerra Peru x Equador mostram que os interesses nacionais precisam ser adequados e direcionados para a integração. A própria América Hispânica, tendo um mesmo ponto de partida e língua e cultura semelhantes, não conseguiu evitar o desmembramento contra o qual Bolívar lançou seus brados. Sua unidade geopolítica não pôde erguer-se devido ao predomínio das oligarquias locais, que não conseguiram articular um projeto político hegemônico, válido para o território inteiro, e não apenas às localidades às quais estavam ligadas- uma incapacidade de projeção espacial de um projeto político.

A expressão América Latina não é, ela própria, natural. Pelo contrário, é fruto da elaboração da diplomacia francesa, na segunda metade do século XIX, que pretendia resguardar a região da influência crescente dos EUA e, claro, projetar a sua. $\mathrm{O}$ ponto alto dessa tentativa de influência sobre o Novo Continente foi a já referida invasão do México, em 1962. O fracasso de Maximiliano é também o fim do projeto francês, cuja influência restringe-se, a partir daí, ao plano cultural ${ }^{5}$. A idéia da América Latina aparece quando o

\footnotetext{
${ }^{5}$ Sobre a origem do conceito de América Latina, ver Magnoli (1997, p.196-197).
} 
bolivarianismo já evidencia seu fracasso e o panamericanismo ganha cada vez mais força.

\begin{abstract}
Outro aspecto discutivel do qualitativo 'ibero-americano' reside no fato de que trai a desconformidade espanhola com a denominação 'América Latina', geralmente aceita para descrever os países de origem latina que se situam entre o México e a Patagônia. No Brasil, a expressão 'América Latina' sempre foi considerada perfeitamente satisfatória, encontrando guarida, inclusive, na Constituição Federal. Aos espanhóis, no entanto, a expressão desagrada por ter sido inventada pela diplomacia francesa no século XIX, no contexto dos malfadados projetos liderados por Napoleão III para 'ajudar' as nações latinas da América, que se haviam tornado independentes de uma Espanha então em declínio, a impedir a expansão dos EUA." (CORRÊA, 1994, p.148).
\end{abstract}

Em suma, o caminho da integração é longo e muito árduo, e o Brasil e o México têm um papel fundamental a desempenhar nesse trajeto.

\title{
As Tentativas de Integração
}

Se a América Latina nunca conseguiu uma maior integração não foi por falta de tentativas. Como já descrito, desde o momento da independência apareceram projetos de resistência à fragmentação. Depois do Congresso do Panamá, o século XIX ainda viu outros congressos com o mesmo intuito: Lima 1848; Santiago, 1856; Lima, 1864-1865; Lima, 1877- 1879; Caracas, 1883; Montevidéu, 1888-188966 - nenhuma teve participação do Brasil. Seitenfus (1989, p.109-111) denomina essas primeiras tentativas de integração de "Fase do Voluntarismo".

Para o pesquisador, a fase seguinte vai de 1889 ( $1^{\text {a }}$ Conferência Internacional das Américas) até 1948 (criação da OEA- Organização dos Estados Americanos). Nessa fase cabe destacar o papel predominante dos EUA e do panamericanismo, ou seja, um enfraquecimento do "latino americanismo". É também a fase das duas grandes guerras mundiais, e o tema da segurança hemisférica ganha maior relevo, sempre conduzido pelos EUA. Além da organização política (OEA) é assinado, em 1947, um acordo de caráter militaro Tratado Interamericano de Assistência Recíproca (TIAR), que inclusive foi resgatado recentemente, após os atentados terroristas nos EUA em 11/9/01.

\footnotetext{
${ }^{6}$ Magnoli (1997, p. 194) aponta o fracasso dessas conferências, e afirma que as três últimas abdicaram das "[...] altas ambições originais, esvaziando-se em encontros de interesse segmentado e temário jurídico ou cultural". Um exemplo é o congresso de Lima de 1877, um congresso de juristas que objetivava uniformizar as legislações americanas em matéria civil- ver Ezcurra (1991, p.82-83).
} 
A terceira fase, marcada pela Guerra Fria, vai de 1948-1986, e é chamada pelo autor de "Panamericanismo Econômico". Apesar do nome, devem ser destacadas as intervenções militares dos EUA na Guatemala (1954), em Cuba (1959) e na República Dominicana (1965), esta última apoiada intensamente pelo Brasil. A forte presença dos EUA pode ser vista também na chamada "Aliança para o Progresso", uma espécie de união hemisférica contra o "perigo comunista" e, mais especificamente, contra o regime cubano.

Mas, paralelamente às iniciativas militares, a segunda metade do século XX teve diferentes impulsos de integração econômica dos países situados abaixo do Rio Grande.

As tentativas de institucionalizar a aproximação dos países latino-americanos remontam à década de 1960, quando foi criada a Associação Latino Americana de Livre Comércio (ALALC)- 1961. Em 1975 foi criado o Sistema Econômico Latino Americano (SELA) e, em 1980, a Associação Latino Americana de Integração (ALADI), sucessora da ALALC. No entanto, o insucesso dessas iniciativas mostrou que a integração regional era dificultada pelos contrastes entre os países, a incapacidade de vencer os desafios postos pela geografia e, principalmente, a forte presença econômica e política dos EUA. Assim, a saída encontrada foi a integração sub-regional, de que são exemplos o Mercosul (1991) e o Pacto Andino (1969).

Todas as experiências de integração econômica foram frustradas e não e levaram ao principal objetivo: o desenvolvimento econômico da região. A integração regional mostrou-se muito difícil pelos contrastes entre os países, a dificuldade de articulação concreta, a distância geográfica e, principalmente, a forte presença econômica e política dos EUA ${ }^{7}$. Assim, a saída encontrada foi a integração sub-regional, de que é exemplo clássico o Tratado de Assunção (1991), que deu origem ao Mercado Comum do Conesul (Mercosul). Em outras palavras, a partir da década de 80 (quando ganharam força as relações bilaterais para acordos sub-regionais), a idéia de uma unidade denominada América Latina perdeu força. Em 1983 foi criado o grupo de Contadora (México, Venezuela, Colômbia e Panamá) e em 1985 o Grupo de Apoio ao Contadora (Argentina, Brasil, Peru e Uruguai). Em 1986 os oito países criaram o Grupo do Rio, que é um fórum de diálogo e coordenação política latinoamericano, mas que não sustenta, a exemplo de seu antecessor de 1983, grandes projetos integracionistas.

O fundamento das tentativas de integração era o mundo polarizado e a

\footnotetext{
${ }^{7}$ Luiz A. P. Souto Maior (1996, p.107-109) identifica duas espécies de tendências de aproximação (regionalismos): o latino - americanismo e o pan - americanismo, que traduzem a alternativa: prioridade aos EUA ou à América Latina.
} 
possibilidade de juntos, os países conseguirem um maior poder de barganha e atraírem mais investimentos. Um exemplo dessa postura foi a Operação Panamericana, promovida por iniciativa de Juscelino Kubtischek, em 1958. Foi uma forma de pressionar os EUA a voltar a atenção para a América Latina, com uma cooperação semelhante ao Plano Marshall na Europa. As expectativas não se confirmaram, mas a iniciativa ajuda a explicar o nascimento do BID (Banco Interamericano de Desenvolvimento), em 1960, que é uma fonte importantíssima de financiamento da América Latina. A fragilidade da unidade latino americana fica evidente quando se lembra que perdeu uma grande possibilidade de atuar de forma coordenada e ganhar, assim, grande poder de barganha: quando foi criada a ONU, em 1955, a América Latina tinha 20 dos 55 membros, o que poderia representar um grande peso internacional se os 20 países agissem em bloco. Essa posição, de qualquer forma, conferiu fundamentos mais sólidos às teses desenvolvimentistas, difundidas principalmente pela CEPAL (Comissão Econômica para a América Latina). Com a entrada na ONU dos países asiáticos e africanos, o peso da América Latina praticamente desapareceu, e com ele a retaguarda do desenvolvimentismo (FERREIRA, 1990, p.60-63).

Cervo (2001) adota a expressão "diplomacia do desenvolvimento", e defende que ela teria começado a partir da década de 30, quando o nacionalismo dos países latino americanos cresceu, e os conflitos internacionais propiciaram um ambiente apto às negociações. A partir da segunda metade da década de 80 ele considera que a nova forma das relações internacionais podem ser denominadas "ciclo da diplomacia neoliberal", que traz novos desafios para o desenvolvimento e a integração regionais ${ }^{8}$.

De qualquer forma, em todos os movimentos de aproximação, o Brasil e o México nunca tiveram uma posição de liderança com esforços mútuos e conjuntos. As relações diretas entre o México e o Brasil sempre foram praticamente inexpressivas (SERRANO; GUADALUPE, 1994). Elas refletem a falta de realidade do conceito de América Latina. Não foi, no entanto, por falta de declarações de apreço mútuo e de intenções de aproximação que esta distância permaneceu enorme. Desde 1822 os representantes diplomáticos de ambos os países manifestam o desejo de estabelecer laços mais estreitos. Em 1824, José Mariano de Michelenas, porta voz do líder conservador Lucas Alamán, manifesta a dois ministros brasileiros: "Os senhores ministros do

\footnotetext{
${ }^{8}$ Em 1987 foi institucionalizado o Parlamento Latinoamericano, pelo tratado internacional assinado por 18 países da região, inclusive Cuba. Ele prevê várias formas de articulação e integração, mas nunca teve uma atuação efetiva. Para se ter uma idéia ele foi fundado em 1964, mas só foi institucionalizado em 1987, quando já findava o ciclo desenvolvimentista. Sobre o assunto ver Ezcurra (1991, p.255 e seguintes), que contém o tratado em apêndice.
} 
Brasil estão convencidos, como eu, do desdém com que é tratada toda a América Latina [...] creio que será muito útil cultivar as relações de amizade com a Nação brasileira e formar com ela um tratado de aliança ofensiva e defensiva, com o único objetivo de assegurar nossa independência." (apud SERRANO; GUADALUPE, 1994).

Apesar do discurso o Brasil, como visto anteriormente, nessa época era alvo de desconfiança dos vizinhos hispânicos e inclusive não participou do Congresso do Panamá, liderado por Bolívar, que tinha grande aversão ao Brasil. Também a forma de governo não era aceita com tanta tranqüilidade, pois a monarquia destoava das repúblicas americanas. Em 1826 especulou-se sobre um acordo bilateral de comércio, que não saiu das idéias. $\mathrm{O}$ século XIX passou com contatos diplomáticos infrutíferos (inclusive alguns de efeito negativo, como o reconhecimento do imperador Maximiliano pelo Brasil), e só em 1922 foi inaugurada a embaixada mexicana no Brasil e vice-versa.

É esclarecedor das frias relações entre os dois países o fato de nenhum presidente brasileiro ter visitado o México oficialmente, até 1962 . E a visita de João Goulart, neste ano, não ganhou muita atenção da mídia nacional, que se concentrou na escala anterior da viagem do chefe do executivo- Washington (MRE, 1962). A viagem de Jango ocorreu dois anos depois que um presidente mexicano, Adolfo López Mateos, pisou pela primeira vez em solo brasileiro. O discurso de Jango não omite as insuficiências do contato diplomático:

Com escasso comércio, com relações políticas sempre cordiais, mas pouco intensas, o Brasil e o México, por mais de um século, evoluíram à distância um do outro, sempre conscientes, porém, das possibilidades de entendimento que uma cultura similar e concepções idênticas para as soluções dos problemas comuns ensejam. (MRE, 1962, p.39).

Atualmente os dois países têm feito acordos setoriais, especialmente no setor automobilístico, tentando incrementar o comércio bilateral, que representa apenas $0,6 \%$ do comércio exterior mexicano e 1,5\% do brasileiro. Segundo a embaixada mexicana no Brasil, "na década de 90 , o comércio bilateral registrou um importante crescimento, passando de US\$ $695 \mathrm{mi}$ lhões, em 1990, para US $\$ 1,5$ bilhão nos últimos três anos" (EMA1) ${ }^{9}$. De qualquer forma, essa aproximação, ainda tímida, é desprovida de qualquer conotação política e não se fundamenta num projeto de fortalecimento e integração da América Latina.

É evidente que uma integração latino americana demanda, como

\footnotetext{
${ }^{9}$ Dados de 2002.
} 
pressuposto, mais do que uma aproximação comercial ou econômica, por meio de uma visão estratégica que a oriente, e, como se mostrará a seguir, ela não foi formada pelos dois países em questão.

\section{A Política Externa Brasileira}

Como já se assinalou, o Brasil começa sua história mantendo o projeto geopolítico português na América: consolidar as fronteiras, manter integro o território e projetar a influência sobre os países vizinhos, mantendo ao menos um equilíbrio na Bacia Platina. Essa política levou o Brasil imperial a um isolamento em relação aos acontecimentos do resto do continente, visto que estava empenhado em manter a ordem interna (10 disputas armadas internas até 1916, como a Sabinada, a Balaiada, Canudos e Contestado e três externas: Guerra do Paraguai e duas campanhas no Uruguai) e consolidar suas fronteiras (Questão de Palmas-1895, Questão do Amapá-1900, Questão do Acre- 1903 e Questão do Pirará-1904). Na delimitação das fronteiras se destacou o trabalho diplomático, de 1902 a 1912, do Barão do Rio Branco, esclarecendo "limites territoriais deixados em aberto pela nulificação do Tratado de Madrid” (ALMEIDA, 1999, p.54).

Assim, o Brasil não pensava nos problemas continentais, senão nos seus próprios. Logicamente às vezes os dois aspectos não eram tão distintos, e era então que o Brasil se colocava como ator internacional na América. Por isso é que, ainda no século XIX não se esforçou por participar dos esforços integracionistas de Bolívar e seu movimento (é claro que, além disso, o Brasil não via com bons olhos seus vizinhos instáveis e republicanos e nem tampouco era bem visto por eles). Nesse sentido o país começou entendimentos com os EUA e, aproximou-se mais da doutrina do panamericanismo do que de qualquer outra. Essa doutrina lhe servia como forma de manter a autonomia em relação à Europa. (MAGNOLI, 1997, p.185-239).

A partir da década de 30 do século XX o Brasil começa a pensar em se impor no sistema internacional de forma mais autônoma. $O$ nacionalismo ganha força, inclusive, contra projetos norte americanos. A política externa de Getúlio Vargas visa fortalecer o país e ganhar mais espaço nas decisões internacionais. Na América Latina o país tinha as atenções voltadas para a Bacia do Prata, mais especificamente para a Argentina. O crescimento do vizinho levava a uma disputa natural por poder e influência na região, traduzida inclusive no desenvolvimento militar (BANDEIRA, 1995, p.33-38). Como se vê, a América Latina não era prioridade estratégica para o Brasil, muito menos sua integração.

O primeiro cenário em que se insere a inserção internacional do Brasil é a expansão ultramarina européia do século XVI. A supremacia da Espanha 
e de Portugal na técnica de navegação permitiu aos dois países dividirem as posses no Atlântico antes mesmo que se confirmassem a existência de vastos territórios americanos. A bula papal Inter Caetera, de 1493, estabelecia a distinção entre as possessões portuguesas e espanholas, garantindo à Espanha as terras descobertas por Colombo, e todo o território americano. No ano seguinte, em 1494, foi assinado o Tratado de Tordesilhas. O novo acordo deixava a Portugal a parte leste da América do Sul, onde viria a se constituir o território inicial da formação do Brasil. O importante é notar que toda a região amazônica estava sob bandeira espanhola, mas será objeto de persistente e sistemática tentativa de conquista e incorporação por Portugal. A tarefa, embora realizada com bastante sucesso pelos lusitanos, só é concluída pelo Estado brasileiro. Em suma, a conquista da Amazônia é uma das principais tarefas herdadas pelo Brasil de Portugal.

Ainda na época colonial, o marco mais importante para a história da formação territorial do Brasil foi o Tratado de Madri, de 1750, pelo qual boa parte da Amazônia passou a Portugal. Tordesilhas foi antes rasgado pelos bandeirantes, que deram bases à expansão portuguesa. Tal movimento de incorporação de fato do território além de Tordesilhas foi impulsionado pela União Ibérica (1580-1640), quando "[...] a expansão territorial foi politicamente facilitada, pois não havia problemas diplomáticos a instigar a diferenciação entre as possessões portuguesas e espanholas." (LAFER, 2004, p. 29). Tal ocupação de fato do território foi justamente o fundamento jurídico do Tratado de Madri- o princípio do uti possidetis.

Goes Filho (1999) sintetiza a formação territorial do Brasil como obra de "navegantes, bandeirantes, diplomatas". No entanto, tendo como foco a região amazônica, salta aos olhos a ausência de um importantíssimo ator na definição das fronteiras do norte: os soldados e os fortes que lhes serviam de base. Em outros termos, é importantíssimo acrescentar à fórmula de Goes Filho o elemento militar, fundamental na defesa ante as pretensões territoriais estrangeiras, notadamente as francesas. As disputas territoriais resultaram inclusive em conflitos militares na região ${ }^{10}$.

A política externa na época colonial foi basicamente voltada para a conquista do espaço e aumento territorial. Ela inseria-se na estratégia portuguesa de expandir seu império por meio das terras de além mar, controlando assim o acesso aos recursos desses locais, bem como as rotas comerciais às

\footnotetext{
10 Sobre a importância do elemento militar na ocupação da Amazônia, bem como dos conflitos bélicos internacionais, ver Meira Mattos (1980, p.32-62). O próprio autor da fórmula "navegantes, bandeirantes e diplomatas" admite que, por não ser objeto de seu estudo, não atentará para as atividades militares na Amazônia, representada pelos fortes. Mas reconhece que "Privilegiando fatores como estes, e não os diplomáticos como faremos aqui, poder-se-iam ter, pois, outras visões da Amazônia” (GOES FILHO, 1999, p. 3).
} 
quais eles serviam de base, na lógica do sistema mercantilista do sistema colonial. No entanto, o povoamento e desenvolvimento da região não foram, a princípio, objetivos portugueses:

O império português é essencialmente marítimo, estruturado como 'uma rede de bases mercantis através do mundo'. Um império 'filiforme', preso aos litorais, cuja imensidão tornava difícil e caro o empreendimento. Um império mantido militarmente, fruto de uma 'conquista talassocrática', que abarcava cerca de cinquenta fortalezas e uma significativa força naval, sem envolver um claro desígnio de efetiva dominação territorial (exceção feita ao Brasil); na verdade, era um controle de rotas oceânicas. (MORAES, 2000, p.74).

Em que pese à colocação do Brasil como exceção à lógica da expansão marítima portuguesa, não houve, até o século XIX, uma pretensão de desenvolvimento do espaço brasileiro. O objetivo prioritário era conquistar e garantir a soberania sobre o território. A mudança mais significativa deu-se com a transferência da corte para o Brasil, movimento que Demétrio Magnoli identificou como movimento de um projeto geopolítico de continuar o império português na América, em 1807 (MAGNOLI, 1997, p.80-83). Mas a presença do Estado Português no Brasil se encerra logo em seguida, com a independência de 1822.

A política exterior do império tem, basicamente, dois intuitos, segundo Demétrio Magnoli: combater a política anti-escravista da Grã Bretanha e consolidar as fronteiras nas bacias Amazônica e Platina (MAGNOLI, 1997, p.131). Celso Lafer considera que a política externa imperial estava voltada, no plano mundial, para a busca de autonomia frente às grandes potências, notadamente a Inglaterra, e regionalmente visava praticar uma política de balanço de poder, que tinha como foco principal de atenção a Argentina (LAFER; PEÑA, 1973, p.85-86).

Outra importante questão para a atuação internacional do Brasil é a relação com os EUA. Diante da política expansionista desse país, quando cidadãos dos EUA começaram a discutir a importância da Amazônia para seu país ${ }^{11}$, o assunto ganha relevo na pauta política do Império. A questão

\footnotetext{
${ }^{11}$ Alguns inclusive propondo o povoamento da região com os negros dos EUA, como o tenente Mathew Fontaine Maury, o principal propagador da idéia de intervenção norte amerciana na Amazônia. Segundo Moniz Bandeira "O secretário de Estado, William H. Seward, instruiu os diplomatas americanos, em 1862, para propor aos países situados dentro dos trópicos que recebessem os negros dos Estados Unidos, libertados pela Guerra Civil. Watson Webb, representante americano junto ao governo do Rio de Janeiro, iniciou as gestões. Os Estados Unidos, conforme a convenção que sugeriu, transportariam, gratuitamente, os ex- escravos para o Vale do Amazonas e o Brasil doaria 100 acres para cada um, cabendo a companhia de colonização, que financiaria o treinamento, o restante das terras. $O$ projeto não encontrou receptividade, tal como aconteceu nos países da América Central" (BANDEIRA, 1978, p.96).
} 
chave da discussão estava na abertura do Amazonas à livre navegação, disputa que opõe os dois países, já que os brasileiros temem que os EUA utilizem esse como o primeiro passo para uma posterior anexação. Embora houvesse quem defendesse no Brasil a abertura à navegação (destacando-se Tavares Bastos), a posição majoritária, tanto no governo como na imprensa, era de que seria preciso resistir às pressões norte americanas, para que não se corresse o risco de perder o território.

A tensão diminui a partir de 1855 , quando os EUA voltam-se para seu conflito interno e, finalmente, em 1866, é assinado o decreto que abre (para navios mercantes) a navegação do Amazonas, Tocantins, Tapajós, Madeira, Negro e São Francisco. Bandeira (1998, p.95) considera que a Amazônia foi responsável pela primeira campanha anti-americana no Brasil. No entanto, Amado Luiz Cervo pondera que o conflito não era tão significativo assim, prevalescendo as relações amistosas:

"As relações entre o Brasil e os Estados Unidos, embora marcadas por atritos ocasionais, pelos quais tinham maior responsabilidade certos agentes insolentes, deveriam pautar-se pelo entendimento de alto nível, porque se vinculavam interesses comuns. $\mathrm{O}$ comércio bilateral era o maior comércio continental, necessário e útil para ambos os lados. A entente cordiale BrasilEstados Unidos fortalecia o 'equilíbrio de poder' Europa-América, uma das metas externas comuns. A singularidade das duas grandes nações do continente aconselhava estrategicamente boas relações recíprocas. Era, em suma, de bom alvitre político superar os conflitos ocasionais.” (BUENO; CERVO, 2001, p.105).

Mas, apesar de alguma importância da região amazônica, não se pode negar que, durante o Império, a principal preocupação da atuação internacional do Brasil estava na relação com a Argentina e com os demais países do Conesul. A ocorrência da Guerra do Paraguai (1865-1870) dispensa maior argumentação para comprovar e explicar essa priorização. A América Latina estava completamente distante.

A finalização da conformação territorial do Brasil pode ser atribuida à gestão do barão do Rio Branco no Ministério das Relações Exteriores (19021912):

Essa busca [de consolidação do espaço nacional] corresponde a um dos sentidos da história do Brasil e foi o primeiro vetor da política externa brasileira- vetor que prevalesceu no período monárquico e se estendeu, até Rio Branco. O tema básico é a ocupação efetiva do território, a sua defesa, em especial na vertente platina dentro da qual se insere a guerra do Paraguai. Este período culmina com a obra de Rio Branco que, com sua ação, equacionou a configuração definitiva de nossas fronteiras." (LAFER, 2004, p.42-43). 
Após a gestão de Rio Branco, e até a década de 1960, a política externa brasileira caracteriza-se pela aproximação dos EUA, concebida prioritariamente pelo próprio Rio Branco. A opção baseava-se na percepção da crescente importância do vizinho do norte no cenário internacional, e da tentativa de construir uma aliança que pudesse conferir maior peso à posição brasileira no concerto dos países.

\begin{abstract}
Nessa interpretação, a gestão do Barão do Rio Branco na Chancelaria (19021912) construiu um marco conceitual para as relações externas do Brasil, ao deslocar de Londres para Washington o eixo da diplomacia brasileira. Seu componente fundamental consistiu na percepção da emergência dos Estados Unidos como futura potência global e eixo necessário da política externa brasileira, levando à busca de uma aliança que possibilitasse o aumento do poder de barganha do país e à aceitação de um vínculo pragmático entre o apoio a posições norte-americanas e a expectativa de ajuda a objetivos brasileiros. Com reinterpretações nas décadas subseqüentes, que levaram a variações seja na sua dimensão pragmática, seja na sua dimensão ideológica, os principais componentes do paradigma da aliança especial com os Estados Unidos foram mantidos por mais de meio século. (MELLO, 2000, p.27) ${ }^{12}$
\end{abstract}

Paralelamente, a estratégia visava permitir uma certa autonomia com relação à Europa, notadamente com relação à Inglaterra (LAFER, 2004). O fundamental é manter o status quo territorial, e, a partir daí, desenvolver o espaço nacional. Para esses objetivos internos é que se volta a política externa.

Os EUA substituem a Inglaterra como potência que serve de principal parceiro e referência para as relações exteriores do Brasil. Assim, a principal ameaça à soberania brasileira na região (os EUA) se torna o principal aliado e parceiro do país, parceria amparada principalmente no incremento das relações comerciais. Tal alteração se reflete no que Bueno (BUENO; CERVO, 2002, p.165-167) denominou a "americanização" da política exterior do Brasil.

A política externa do país foi marcada, no período 1946-1961, por um alinhamento aos EUA, exemplificados pela assinatura do Tratado Interamericano de Assistência Recíproca (1947), a Comissão Mista BrasilEUA (1950) e o Acordo de Cooperação Militar (1952). Além da justificativa econômica para tal alinhamento, não se pode esquecer a conjuntura mundial, em que a Guerra Fria estruturava as relações internacionais. Nesse contexto, é menor o espaço para um projeto voltado para os vizinhos latino-americanos. Tanto o Brasil como a América Latina aparecem no sistema internacional

${ }^{12}$ Ver também Bueno (2003, p. 319-320). 
como área de influência dos EUA, e atuam de acordo com essa condição.

Não se pode deixar de mencionar o contexto desenvolvimentista, projeto que caracterizou a história do país da década de 1950 à de 1980, amparado em doutrinas da Comissão Econômica para a América Latina e o Caribe (CEPAL), fundada em 1948, da Escola Superior de Guerra (ESG), criada em 1949 e do Instituto Brasileiro de Economia, Sociologia e Política (IBESP), nascido em 1953 e depois transformado em ISEB (Instituto de Estudos Brasileiros). A ocupação e aproveitamento econômico do imenso território nacional passaram a ser objetivos prioritários para os sucessivos governos brasileiros, e a construção de Brasília, com a conseqüentemente transferência da capital nacional para o interior (1960), é um símbolo dessa meta de conquista do próprio território.

No plano externo a política externa também visava, desde a década de 1950, o desenvolvimento do país ${ }^{13}$. As estratégias internacionais para o desenvolvimento, no entanto, eram variáveis. E um dos principais elementos dessa estratégia é a relação do Brasil com os EUA e a América Latina. De 1946 a 1950, logo após o término da Segunda Guerra e o início da Guerra Fria, a política externa caracterizou-se, como já mencionado, pelo alinhamento aos EUA. Os governos que sucederam Dutra (Vargas, Café Filho e JK) continuaram, até 1961, uma política de colaboração e aproximação com os EUA, porém reforçando os elementos de barganha e buscando vantagens em troca desse apoio, política que ganhou a denominação de "desenvolvimento associado” (BUENO; CERVO, 2002, p.273-307). Exemplo dessa postura é a proposição, por Juscelino Kubitschek, da Operação Panamericana, uma tentativa de converter a aliança política e estratégica em apoio econômico. Ainda assim, o período é marcado pela referência que os EUA representavam para a política externa brasileira, deixando pouco espaço para um projeto latino- americanista.

A partir de $1961^{14}$, o Brasil adota a política externa independente, que colocava, acima de um compromisso com os EUA e com a Guerra Fria, os objetivos próprios do país. Assim, relações com o mundo comunista foram reatadas e/ou reforçadas (Europa Oriental China e URSS) e a tônica foi a diversificação dos parceiros internacionais, com a aproximação de países africanos. No ano de 1961, o governo dos EUA anunciou a Aliança para o Progresso, programa pelo qual prometeu destinar 20 bilhões de dólares para

\footnotetext{
13 "[...] a política externa brasileira, principalmente a partir dos anos sessenta, constituiu-se num instrumento atrelado à política nacional de desenvolvimento". (OLIVEIRA, 1994, p.2).

${ }^{14}$ Importante lembrar que, como já mencionado, em 1960, surge a primeira tentativa institucionalizada de integração da América Latina, a Alalc (Associação Latino Americana de Livre Comércio). Mas a Alalc, por razões variadas, fracassou (KUNZLER; MACIEL, 1994, p.152-153).
} 
o desenvolvimento da América Latina nos 10 anos seguintes (BUENO; CERVO, 2002, p. 323), como forma de reforçar sua influência no continente. Cuba representava um exemplo preocupante para a Casa Branca. Houve uma aproximação diplomática do Brasil com a América Latina se deu em vista de entendimentos com a Argentina, expressa em acordos de cooperação (BUENO; CERVO, 2002, p.330-331), e com o Chile, expressa pela visita oficial de João Goulart a Santiago e com o México, com a visita do presidente brasileiro em 1962.

Ainda que a política externa independente de Jânio e Jango pudesse representar uma certa aproximação (resssalte-se: diplomática) da América Latina, possibilitada pela pretensa autonomia frente aos EUA, o norte da América do Sul, bem como a América Central, continuam sendo áreas alheia à realidade brasileira nesse período.

No período após o golpe militar no Brasil, as relações com a América Latina pioram, pela política brasileira de realinhamento com os EUA, além da teoria do cerco, que reservava aos vizinhos hispânicos um olhar desconfiado e atento, pronto para reagir a qualquer "contratempo", por fim, o eixo Norte-Sul da política externa é substituído pelo Leste- Oeste (VIZENTINI, 1998, p.31-32). A estratégia do Brasil era colocar-se como aliado preferencial dos EUA contra o perigo comunista, na tentativa de conseguir deste país recursos parafortalecer o poder nacional ${ }^{15}$.

A participação do Brasil na intervenção na República Dominicana (1965), por meio da Força Interamericana de Paz, mostra aos demais países da América Latina que o apoio aos EUA poderia significar medidas de força na região, ainda que se considere que o Brasil agisse em função de seu interesse nacional, e não como mandatário de interesses externos. No Chile, em 1966, o chanceler brasileiro Juracy Magalhães declarou-se enfaticamente contrário à formação de blocos econômicos na América Latina (VIZENTINI, 1998, p. 50).

O governo de Costa e Silva passa da prioridade à segurança para a prioridade ao desenvolvimento, motivo por que sua política externa é denominada “diplomacia da prosperidade" (VIZENTINI, 1998, p.84-92). Com relação aos

\footnotetext{
15 Oliveiros Ferreira (2001, p. 48-53), divergindo da maior parte da literatura a respeito, não vê grande diferença na política externa de Castelo Branco, Costa e Silva, Médici e Geisel. Para o autor, a essência da posição do Brasil é a mesma (as diferenças seriam apenas táticas, e não estratégicas): o interesse em ser ouvido pelos fortes e respeitado pelos fracos, partindo de um planejamento geográfico dos interesses - os círculos concêntricos, que mostram a América Latina como área prioritária ao interesse nacional, seguida pelo continente americano e o "Ocidente". Independente das divergências da literatura, que não cabe avaliar por não serem objeto de pesquisa e portanto, não haver material empírico para tal comparação, o que importa aqui é perceber que, acertada ou não a política externa de Castelo Branco, a postura do Brasil não era percebida como simpática pelos vizinhos.
} 
EUA procura manter uma certa autonomia, evidenciada principalmente nas divergências sobre o Tratado de Não Proliferação Nuclear (1967). Na Bacia Platina, foi assinado, em 1969, o Tratado da Bacia do Prata ${ }^{16}$, um projeto de integração física dos países platinos, que prevê um órgão permanente- o Comitê Intergovernamental de Coordenação. No mesmo ano é formado o Pacto Andino $^{17}$, configurando os dois pólos de integração da América do Sul. Por parte do Brasil, o governo adota um discurso mais palatável para os vizinhos.

O sucessor de Costa e Silva, Médici, adota uma postura mais "individualista”, que vislumbra o Brasil Potência sem necessariamente adotar um discurso terceiro mundista ou multilateralista. No lugar negociações multilaterais, o país optou por acordos bilaterais com seus vizinhos:

O realismo da Diplomacia do Interesse Nacional liberava o Brasil de pactos ou acordos de solidariedade e lhe permitia seguir caminhos exclusivamente bilaterais que não prejudicavam sua ascensão ao primeiro mundo. Antes disso, o Brasil encontrava-se diante de duas alternativas de desenvolvimento: 1) integração com os países da região ou 2) tentativa isolada no caminho do desenvolvimento e da autonomia internacional. A opção pela segunda foi influenciada por condicionantes externos [...] A política externa do governo Médici produziu enorme desconfiança por parte dos demais países da América Latina. (VIZENTINI, 1998, p.145, 151).

As variações na postura internacional do Brasil não contribuíram com a incorporação de um projeto latino americano. Nas relações continentais, a complicada oscilação entre os EUA e a América Latina deixou muitas vezes um sentimento de desconfiança no grupo de países que compõe esta última.

O governo Geisel (1974-1979) foi marcado por uma relação pouco amistosa com os EUA, simbolizada pelo acordo nuclear com a República Federal da Alemanha (1975), pelo relatório sobre os direitos humanos feito pelo governo Carter e pela denúncia do acordo militar com os EUA, bem como dos demais instrumentos de cooperação (1977). Paralelamente à postura de autonomia frente aos EUA, e de diversificação dos parceiros internacionais (URSS, China, Leste Europeu, Europa Ocidental, Japão etc) o período mostra uma certa aproximação do Brasil com relação à América Latina.

O eixo leste-oeste das relações internacionais é definitivamente relativizado, com significativas aberturas para uma atuação conforme o eixo norte-sul. Com Geisel e Azeredo da Silveira, e seu "pragmatismo responsável”, consolida-se o paradigma de atuação externa iniciado com a política

\footnotetext{
${ }^{16}$ Integrado por Argentina, Bolívia, Brasil, Paraguai e Uruguai.

${ }^{17}$ Originalmente formado por Bolívia, Chile, Colômbia, Equador e Peru. Em 1973 a Venezuela ingressa no Pacto e, em 1976, o Chile se retira.
} 
externa independente, caracterizado pela busca por autonomia nos sistema internacional, notadamente com relação aos EUA. Por essa perspectiva, o Brasil deveria transcender o sistema interamericano como área de priorização exclusiva do país ${ }^{18}$, pois ao restringir sua atuação a elemento desse sistema, o país ficava sujeito aos interesses norte-americanos, e apareceria internacionalmente meramente como um de seus aliados.

Desde a política externa independente, mas principalmente com o pragmatismo responsável, o Brasil busca justamente marcar seu peso específico no cenário internacional. Com o rápido desenvolvimento econômico, apoiado no impulso industrializante das décadas de 1940 e 1950, e fortemente acelerado nas décadas de 1960 e 1970, o enorme contingente populacional, um dos maiores territórios do mundo e uma abundante disponibilidade derecursos naturais, o país desejava ganhar seu próprio espaço no cenário mundial ${ }^{19}$, desvinculado da imagem de apêndice dos EUA.

A aproximação da América Latina e de outros países (inclusive externos ao bloco Ocidental) tinha não só uma motivação econômica (diversificação de mercados e parceiros), mas também era motivada por uma pretensão, amparada nos fatores de poder citados, de o Brasil alcançar uma certa liderança no bloco dos países menos desenvolvidos.

Desenvolvimento interno e projeção internacional. Para alcançar esse duplo objetivo, a política externa, sob o governo Geisel, adotou uma postura heterodoxa, sem nenhum determinante externo prévio, sem restrições geográficas ou ideológicas. E a América Latina ganha destaque no discurso da diplomacia nacional ${ }^{20}$. Mas, apesar das regularidades, é importante atentar para o fato de a política externa, assim como qualquer espécie de política, ser um campo em que contradições, visões conflitantes e disputas de interesses se conjugam no perfil final. Ou seja, "pragmatismo responsável”, "política externa independente”, "prioridade à América Latina” são concepções genéricas e elucidativas, mas sob as quais se escondem diversas nuances.

\footnotetext{
${ }^{18}$ Evidentemente sempre houve relações com outras partes do mundo (antes da Primeira Guerra, por exemplo, o governo de Vargas tinha uma clara oscilação entre a Alemanha e os EUA). Mas o que se argumenta é que, até a década de 1960, os EUA e o sistema interamericano eram as referências máximas e prioritárias da política externa brasileira, deixando os demais espaços do globo como alternativas secundárias do horizonte internacional do Brasil.

${ }^{19}$ Para ilustrar essa mudança de concepção própria do país, podem-se citar dois livros de geopolíticos brasileiros. O primeiro, escrito em 1931, por Mario Travassos (1938), chama-se "Aspectos geográficos Sul-Americanos" e, a partir da segunda edição de 1935, seu título muda para "Projeção continental do Brasil". Em 1960 o general Carlos de Meira Mattos escreve "Projeção Mundial do Brasil”, e explica no prefácio que a conjuntura permite passar da ambição de projeção continental para uma mundial.

${ }^{20}$ É consensual que a América Latina passa a ser apresentada (desde o governo Médici, na verdade) como prioridade das relações internacionais do Brasil. Vizentini (1998, p. 226), entretanto, considera que a prioridade à região limita-se ao disurso. Já Cervo (BUENO; CERVO, 2002, p. 419) destacam o significado político e comercial de tal aproximação.
} 
Com relação à aproximação da América Latina e dos países menos desenvolvidos, é o próprio Geisel quem esclarece que a idéia deve ser relativizada:

Mas creio que o problema do Brasil é, principalmente, econômico. Dele derivam os demais, inclusive o social. A fome do povo, o desemprego do povo, os assaltos, os roubos, o tráfico de entorpecentes tem a sua raiz na nossa deficiência econômica. Seremos uma nação de maior expressão se conseguirmos desenvolver a nossa economia. Eé no Heminsfério Norte que há mercados, tecnologia, ciência, tudo que nos interessa e nos é necessário para o nosso desenvolvimento. Isso não quer dizer que se ignore o resto, mas numa escala de valores dou preponderância ao Hemisfério Norte, independente de considerações geopolíticas (GEISEL, 1998, p.354-355).

Também a postura de maior autonomia frente aos EUA não era um consenso no governo. A disputa de concepções era personificada nas figuras do chanceler Azeredo da Silveira, que defendia um maior distanciamento dos EUA, e do ministro da fazenda Mario Henrique Simonsen, que pretendia uma colaboração mais intensa com os norte-americanos (D'ARAÚJO; CASTRO, 1998, p.359-360). Há ainda que se levar em consideração uma diferença de concepções do Itamaraty para setores militares do governo, expresso principalmente pelo Conselho de Segurança Nacional (GONÇALVES; MYAMOTO, 1993, p.211-246).

Em meados dos anos 80, ao mesmo tempo em que a democratização fazia grandes progressos no continente, a marcha do processo integracionista na América Latina parecia não conseguir superar a dimensão da retórica bem intencionada. Num mundo em acelerada transformação econômica e tecnológica, os países membros da ALADI passavam por uma severa crise de ajustamento externo, o que induzia políticas de cunho protecionista e a redução sensível do comércio intra-regional. Na realidade, pode-se afirmar, hoje, que naquele momento desenvolvia-se uma sutil, algumas vezes explícita, oposição ao aprofundamento dos mecanismos de natureza multilateral regional. A necessidade premente de buscar divisas fortes lançava a segundo plano compromissos idealistas contraídos no começo da década. Em suma, o continente, ainda apegado ao modelo de substituição de importações, parecia continuar seu caminho na contramão das tendências mundiais (BARBOSA; CÉSAR, 1994, p. 292)

A política externa do governo Figueiredo (1979-1984) não apresenta grandes rupturas com a linha de Geisel. A grande diferença está no contexto internacional, em que os países desenvolvidos reforçam seu protecionismo, o que leva o país a reforçar sua postura terceiro-mundista e sua participação ativa em fóruns multilaterais, como as reuniões da UNCTAD, do grupo dos 
77, da Assembléia geral da ONU e do GATT. O rótulo de "pragmatismo responsável” foi substituído pelo de "universalismo”. A complicada situação econômica interna, bem diferente da conjuntura da década anterior, deixou claro que o país tinha meios limitados para sua atuação internacional, restando a alternativa de se juntar com os demais prejudicados pela ordem internacional para reivindicar sua alteração ${ }^{21}$. Merece destaque também a resolução dos desentendimentos com a Argentina, na questão de Itaipu.

O governo Sarney (1985-1989) mantém, externamente, as mesmas linhas de Figueiredo, mas tem como destaque os protocolos de entendimento com a Argentina (LAFER, 2004, p.103-107; MELLO, 2000, p.50-57).

O processo de entrosamento com o vizinho platino é a característica mais importante da política externa do governo Sarney, já que é o antecedente direto do principal assunto externo brasileiro dos anos seguintes: o Mercosul. Em relação à América Latina há uma aproximação significativa, mais privilegiando a característica terceiro-mundista do que em atenção a qualquer especificidade local. As relações externas do país continuam a se universalizar, tendo como exceção à continuidade o reatamento das relações com Cuba (1986).

Um dado inicial ${ }^{22}$ para a política externa brasileira nos anos 90 é a iniciativa para as Américas, proposta pelo presidente dos EUA, George Bush, em 1990 (antecedente da proposta da Área de Livre Comércio das AméricasALCA). Tal empreendimento poderia significar um empecilho à estratégia de autonomia da inserção internacional do Brasil. Outro dado básico, e correlato ao primeiro, é a assinatura do Tratado de Assunção, em 1991, que criou o Mercosul, o foco primordial dos esforços diplomáticos brasileiros a partir dessa data. Quando se diz que o Mercosul é correlato à ALCA significa que ele faz parte da estratégia brasileira de negociar em bloco com o mundo, tentando juntar forças para garantir uma maior consideração dos países desenvolvidos, principalmente os EUA ${ }^{23}$. Percebe-se claramente que a opção regional brasileira está na bacia platina.

Mello $(2000,2001)$ sintetiza a política externa brasileira a partir do

\footnotetext{
${ }^{21}$ Sobre a política externa do período ver Mello (2000, p.24-27) e Bueno e Cervo (2002, p.427439).

22 Não se pode deixar de mencionar outro fato da maior importância, a estruturar não só as relações internacionais do Brasil como as do mundo todo: o desmoronamento da União Soviética e o conseqüente fim da Guerra Fria, simbolizados pela queda do Muro de Berlim, em 1989.

23 "Desde então, o Brasil foi o único país da América Latina que, de alguma forma, resistiu a todas as iniciativas dos EUA para a região, mantendo os mesmos objetivos estabelecidos em 1990: assegurar a atuação conjunta do Mercosul para fortalecer seu poder de barganha nas negociações com Washington; evitar a defecção da Argentina; tentar alterar a natureza unilateral da proposta norte-americana; e impedir que o bloco sub-regional viesse a ser diluído caso a área de livre comércio hemisférica fosse efetivamente deslanchada." (MELLO, 2001, p. 3).
} 
início dos anos 90 como de regionalização. Lafer (2004) acrescenta à idéia de regionalização a de inserção no mundo globalizado. Na verdade, como mostra Mello (2000, p.78), o governo Collor pode ser dividido em duas fases: uma inicial, de cisão com o paradigma de autonomia, e uma segunda, a partir da nomeação de Celso Lafer no Ministério das Relações Exteriores, em 1992, de retorno ao não alinhamento automático.

O governo de Itamar Franco continuou com a mesma linha de política externa, e os dois governos Fernando Henrique Cardoso foram marcados pela prioridade absoluta à América do Sul como espaço da atuação brasileira, ao mesmo tempo em que o país se esforçava para marcar posição nos assuntos globais.

Mas o fato é que como ator regional ou como ator global, o Brasil deu mais atenção a questões de estruturação e fortalecimento do Mercosul, liberalização comercial (com o combate ao protecionismo dos países desenvolvidos), fluxos de investimentos, balança comercial, dívida externa etc. De modo que não restou espaço para a América Latina.

[...] nesta virada do século, a economia da geografia aconselha um novo enfoque para o conceito de América Latina. De fato, há de ter em conta que o México, em função de sua participação no NAFTA e a América Central e o Caribe, por obra da ação centrípeta da economia norte americana, viram o seu grau de independência com o Norte aumentar ainda mais significativamente nos últimos anos. Por esse motivo, o futuro dessa parte da América Latina está cada vez mais vinculado ao que acontece nos EUA. A América do Sul, em contraste, tem relações regionais e internacionais mais diversificadas, tanto no plano econômico como político. Este é um dado da realidade contemporânea que lhe confere uma especificidade própria no contexto da América Latina, da qual cabe extrair as apropriadas conseqüências em matéria de política externa. (LAFER, 2004, p.55) ${ }^{24}$.

\section{EUA: O Norte do México}

Na história da política externa mexicana, é impossível que se ignore a determinação de um dado geográfico: a vizinhança dos EUA. A ligação entre os dois países é carnal, visto que 50\% do território original mexicano hoje integram o território dos EUA. Desde o início do século XIX, não se pode compreender a história do continente americano sem que se atente para a posição e atuação dos EUA. Esse país, em plena ascensão econômica, baseava sua política externa nas doutrinas do destino manifesto, a justificar sua expansão territorial e na doutrina Monroe, que propugna pelo afastamento dos países europeus da política americana, reservando o continente à preponderância estadunidense. Inspirada nessas concepções, os EUA praticaram, no

${ }^{24}$ Note-se que, quando escreveu o livro o autor era o ministro das relações exteriores do Brasil. 
século XIX, verdadeira política expansionista, anexando enormes territórios, principalmente do México (Texas, Califórnia e Novo México) ${ }^{25}$.A estratégia de conquista era feita em quatro fases: "penetração demográfica, provocação, conflito e anexação” (BUENO; CERVO, 2002, p. 102).

Desde a sua independência (em 1821) até o início do século XX, a grande preocupação internacional do México era a ameaça representada pelos EUA, que considerava os assuntos políticos da América Central e do Caribe praticamente como assuntos internos, com destaque para a importância estratégica do Canal do Panamá.

Esse relacionamento inicial pouco amistoso determinou uma perspectiva de resistência e desconfiança no México, que sempre tentou manter sua independência com relação aos EUA e orientar sua política por seus próprios interesses.

A tendência foi reafirmada e reforçada pela Revolução Mexicana, iniciada em 1910. A primeira grande marca do movimento foi à reforma agrária realizada, medida que tem fortes implicações internacionais, já que atenta contra interesses privados capitalistas de grupos estrangeiros, principalmente norte americanos. Basta citar, para exemplificar, que, em 21 de abril de 1914, a invasão do México por mil fuzileiros navais norte americanos quase desencadeou uma guerra entre os dois países, evitada pela mediação de Brasil, Argentina e Chile. Em 1927 a relação entre os dois países volta a recrudescer, quando o congresso mexicano aprova leis contrárias aos interesses de empresas petroliferas dos EUA, em especial a Standart $\mathrm{Oil}^{26}$. Mais uma vez a situação se aproximou do conflito bélico. Na ocasião o presidente do México, Plutarco Elias Calles, ordenou ao comandante militar das zonas petroliferas, general Lázaro Cárdenas, que incendiasse os campos de petróleo no caso de uma invasão norte americana (BANDEIRA, 1998, p.43, 49).

A partir de 1934 assume a presidência o próprio Lázaro Cardenas, que retoma a radicalização do processo revolucionário iniciado em 1910. Internamente é aprofundado o processo de reforma agrária, bem como de enfrentamento de interesses privados internacionais. Foi essa postura que levou o país a nacionalizar as empresas de petróleo, o que não agradou nem um pouco os EUA:

\footnotetext{
${ }^{25}$ Houve inclusive quem, como o secretário de Estado norte americano James Buchanan, defendesse nessa época a conquista de todo o México (BANDEIRA, 1998, p.17).

${ }^{26}$ As leis foram aprovadas de acordo com a constituição de 1917, fruto da Revolução. Embora o texto constitucional mostra a vitória de interesses moderados e burgueses na condução do movimento, ele determina que toda a propriedade é originariamente do Estado mexicano, podendo seu domíno ser cedido a particulares. Além disso, o direito de propriedade está expressamente limitado pela determinação do interesse público, estando sujeito a intervenções pelo poder público. Sobre a Constituição mexicana de 1917 ver, por exemplo, Altman (2002, p.15) e Corrêa (1983, p.103-106).
} 
A nacionalização, em 1938, das empresas petrolíferas que atuavam no México, por um decreto de 18 de março do presidente Lázaro Cardenas, suscitou forte interesse no continente americano. O Departamento de Estado interferira no caso, com o intuito de mediar o acerto para indenização das empresas americanas expropriadas, mas, diante das dificuldades, retirou-se para não ferir sua política de boa vizinhança (CERVO, 2001, p.74).

Desde a década de 1930 é reforçada a política externa que busca a autonomia. Isso se refletiu no apoio incisivo à Revolução Espanhola (1936), inclusive com o envio de armas, petróleo e açúcar e também no asilo concedido a Leon Trotsky no mesmo ano. Ambas as atitudes diferenciaram o México no plano internacional, mostrando que sua presença nas relações internacionais era movida por valores próprios. Em decorrência, a bandeira da autodeterminação dos povos tornou-se uma sólida raiz da política externa mexicana, manifesta, por exemplo, em condenações às intervenções norte americanas no Caribe. Esta política se prolonga pelos sucessores de Cardenas, mesmo aqueles de perfil mais conservador. Em 1954 o México condena a intervenção dos EUA na Guatemala e, em 1965, na República Dominicanaesta última apoiada decisivamente pelo Brasil.

No advento da Revolução Cubana, o México foi contrário ao isolamento da ilha, acompanhado pelo Brasil até 1964 (quando o governo militar brasileiro rompe as relações diplomáticas com o governo de Castro). Ambos os países impediram que a Organização dos Estados Americanos (OEA) refletisse a posição dos EUA ${ }^{27}$.

Ao contrário do Brasil e de outros países latinoamericanos, o México evitou os acordos bilaterais e a cooperação militar com os EUA, chegando a rejeitar sua ajuda. Com profunda desconfiança dos EUA, o México não procurava nem desejava manter um relacionamento próximo com seu vizinho do norte e, com frequência, opunha-se à posição dos EUA em fóruns internacionais. Seu histórico de votações nas Nações Unidas alinhava-se mais com Havana do que com Washington. (HAKIM, 2002, p.100).

É de se notar, no entanto, que a tradição de autonomia da política externa mexicana se expressa também num certo isolamento. Em outros termos, não houve de fato um perfil de aproximação regional ou latino americana. O nacionalismo vindo do século XIX e reforçado pela Revolução do século XX é o determinante principal da política exterior do país.

\footnotetext{
$27 \mathrm{Na}$ literatura há interpretações diversas sobre a posição Mexicana com relação a Cuba. Alguns autores consideram que a política foi de não envolvimento, mas sem por isso alinhar-se aos EUA (ver, por exemplo, PELLICER, 1985, p.271). Outros consideram que a participação mexicana em Cuba foi mais ativa (ALTMANN, 2002).
} 
Ao mesmo tempo em que o México procurava manter-se independente dos EUA, não tinha grandes pretensões de confrontá-lo numa disputa pela influência no Caribe e na América Central. Essa região então sempre apareceu como interesse secundário na formulação da política exterior mexicana. O restante da chamada América Latina sempre situou-se ainda mais distante da política internacional do país. Um dos fatores que explicam tal opção política é o objetivo interno de promover o desenvolvimento. O desenvolvimentismo mexicano pautou-se, dos anos 1960 a 1980, na exportação de petróleo e outros produtos primários e, principalmente, no financiamento por crédito externo. Em qualquer dos casos, não eram os países subdesenvolvidos ou em desenvolvimento os parceiros prioritários.

Houve alguma alteração significativa a partir de 1979, em razão de um maior engajamento nas questões da América Central a partir da tomada do poder pelos sandinistas na Nicarágua, e em razão da crise da dívida que explodiu em 1983. A adesão ao Grupo de Contadora, formado em 1982 por México, Colômbia, Panamá e Venezuela, mostra a aceitação de uma ação multilateral, o que não é comum na história da política exterior mexicana, em que prevalecem as soluções unilaterais ou bilaterais. As razões de um posicionamento mais ativo devem-se à intenção de se evitar um conflito militar generalizado que certamente geraria problemas devidos à imigração na fronteira sul.

Além disso, um conflito militar na América Central colocaria em cheque um dos principais marcos da autonomia do México- a sua concepção de segurança nacional distintada concepção de segurança nacional dos EUA, moldada esta pela Guerra Fria.

A própria organização das forças armadas demonstra o ímpeto de autonomia que orienta a política externa mexicana. As forças armadas só podem sair do território mexicano, segundo a Constituição, mediante declaração de guerra, ou quando os interesses nacionais do país estiverem ameaçados ${ }^{28}$. Não pode, portanto entrar como aliado em conflitos internacionais que não atendam um dos dois requisitos, ou seja, não pode mandar forças de apoio em missões de organismos internacionais, a não ser em caso de catástrofes da natureza. Mesmo no caso da Segunda Guerra Mundial, o país só entrou no conflito quando um petroleiro seu foi afundado pela Alemanha.

No início dos anos 1980, então, o México vai conciliar duas posturas diferentes: por um lado a forte oposição ao isolamento da Nicarágua, dispendendo esforços para promover a paz na região, em oposição aos planos

${ }^{28}$ Informações do texto "Seguridad Nacional y Relaciones Exteriores en el Mexico de fin de siglo, que pode ser encontrado no site Agora.Net, no seguinte endereço: www.agora.net.mx/analisis/ benitez.htm. 
belicistas de Washington; e por outro lado uma tentativa de negociar com seus credores (em sua maioria norte americanos) uma reestruturação da dívida. De qualquer forma, em qualquer das tendências marcantes do início da década de 1980, a América Latina está longe de representar uma prioridade ou mesmo de ser considerada como uma alternativa estratégica.

A primeira experiência obtida com o esforço do SELA/CEPAL para discutir as possiveis formas de acerto entre os países da América Latina, objetivando um melhor manejo dos problemas da dívida, revelou que os 'grandes' (Argentina, Brasil e México) não aceitam facilmente uma ação comum com os outros países da região. Na realidade, não parece existir condições para que o México patrocine um regionalismo indiscriminado que o situe plenamente no bloco latino-americano, ou num terceiro mundismo generalizado [...] (PELLICER, 1985, p.270).

Apesar da postura combativa relativa à América Central, a questão econômica levou o México a buscar negociações bilaterais com os EUA e os credores, obtendo um relativo sucesso na reestruturação da dívida externa, mas submetendo-se a condições de ajuste fiscal bastante rígidas, medidas que se difundiram pela América Latina principalmente a partir da década de 1990.

Contrariamente ao que ocorre com a percepção mexicana da crise centro americana, e sua resposta colegiada ou combinada pela via da atuação decidida do país no Grupo Contadora, o reconhecimento mexicano da dura crise financeira enfrentada desde 1982 pela nação e pelos outros países da América Latina- especialmente Brasil, Argentina e Venezuela- não dá lugar a uma reação similar (colegiada ou combinada). Pelo contrário, o México retoma a individualidade nas suas decisões e sua reação se expressa em cânones tradicionais da negociação bilateral, apegando-se irrestritamente à crença de que por este caminho se obtêm mais vantagens, ignorando ou escamoteando a deteriorização da capacidade de negociar favoravelmente, quando essa se encerra em visões estritamente nacionais. (GREEN, 1985, p.289-290) ${ }^{29}$.

A política externa mexicana sofreu uma grande transformação na década de 90, mais especificamente a partir de 1994, quando entra em vigor o Nafta (North American Free-trade Agreement ou Acordo de Livre Comércio da América do Norte). A política de não alinhamento é substituída.

A partir de 1990, no entanto, o México começa a negociar um acordo de livre comércio com os EUA, que entra em vigor em 1994. Isso faz deste país o principal aliado mexicano. O comércio exterior passou a ser a base da economia do México e a abertura de seu mercado para o comércio mundial

\footnotetext{
${ }^{29} \mathrm{O}$ autor critica a incapacidade de os países latino americanos (México inclusive) não conseguirem coordenar suas ações, argumentando que isso poderia aumentar seu poder de barganha, e propõe o estabelecimento de etapas para a articulação gradual dos países.
} 
é muito grande (HAKIM, 2002, p.94).

O problema da Segurança Nacional deixa de ser autônomo, e entrelaça-se com a Segurança Nacional dos EUA. Portanto, entram na pauta a questão do narcotráfico, das imigrações e do terrorismo. O cultivo de maconha e ópio iniciado pelos EUA em território mexicano, na época da Guerra do Vietnã, torna-se um grande problema de segurança, pois quando os EUA não precisaram mais dessa droga para amenizar o sofrimento de seus soldados, tornaram o seu combate uma bandeira fundamental nas relações internacionais. E restou ao governo mexicano a difícil tarefa de combater o narcotráfico, ainda que o principal mercado consumidor continue fora de suas fronteiras: justamente nos EUA.

Não se pode deixar de notar, no entanto, que aproximação comercial dos EUA foi uma estratégia, bem sucedida, é bom que se diga, de superação da fortíssima recessão econômica de que foi vítima toda a América Latina na década de 80- na década de 90 as suas exportações cresceram 15\% ao ano. Seja como for, independente das fases históricas, os EUA sempre foram o parâmetro da política externa mexicana, ou seja, em nenhum momento o México pôde pensar uma inserção internacional sem que a principal variável seja sua postura com seu vizinho do Norte.

O México sempre foi uma espécie de satélite econômico dos Estados Unidos. A gigantesca economia dos EUA, 20 vezes maior que a do México, exerce enorme força gravitacional sobre as exportações e mão-de-obra mexicanas. O Nafta amarrou ainda mais a economia mexicana à americana: sua fração de exportações para os EUA subiu de $75 \%$ para $90 \%$. Ao comprar produtos mexicanos, enviar capital e turistas e alimentar o fluxo das remessas de trabalhadores (mais de US $\$ 8$ bilhões por ano) para o vizinho ao Sul, a economia americana livrou o México de sua crise em 1995 e alimentou cinco anos de crescimento constante, em média 5,5\% ao ano, no período de 1996 a 2000. Este ano, a claudicante economia americana arrastou o México para a recessão (HAKIM, 2002, p.97).

\section{Considerações Finais: A Difícil Opção Pela América Latina}

Este trabalho pretendeu mostrar, de uma perspectiva histórica, a fragilidade da idéia da América Latina. A posição internacional do México e do Brasil ilustram bem a dificuldade de se concretizar esta idéia, de forma que uma integração latino americana está tão distante como a aproximação maior entre os dois países. Exatamente pelo fato de eles representarem extremos difíceis de conciliar: de um lado o vínculo com o norte e o mundo desenvolvido, de outro a colonização portuguesa e a ameaça de "subimperialismo". Em outras palavras, México e Brasil encarnam, simbolicamente e de fato, todos os obstáculos que precisam ser superados para que se concretize a 
unidade de fato da América Latina: fatores históricos, geográficos e, principalmente, de opção política - todos associados a um fator determinante: a forte presença dos EUA e sua importância econômica para todos os países do continente.

Nunca o México e o Brasil juntaram forças para construir uma unidade nessa região. Isso não quer dizer que a decisão seria simples ou mesmo exitosa. Mas o fato é que sem a opção firme e decidida dos dois países, a região estará condenada a ser sempre um espaço privilegiado de acumulação do capital, em prejuízo para a maioria da população.

A América Latina nasce no momento da formação do sistema mundial. Por isso é impossível pensa-la separadamente do resto do mundo. Compreender que a região é a periferia de um sistema internacional é fundamental para que se esclareça que, nesse sistema, não há alternativa possível. Mas para enfrentar tal desafio não basta a atuação isolada de um ou outro país. Não basta lançar brados contra o imperialismo e o capital. É preciso que se construa um projeto concreto, conjunto. E este só pode vir da soma de esforços. Infelizmente, nem os estrategistas nem os movimentos sociais conseguiram, até agora, conceber esse projeto político de atuação conjunta, que pudesse dar realidade à idéia da América Latina e, mais do que isso, a um projeto alternativo de sociabilidade que permitisse que os povos que vivem nessa região se tornassem livres da dominação e exploração a que são submetidos.

Optar pela América Latina significa não se restringir a indicadores econômicos, mas fazer dessa integração um verdadeiro projeto político e, mais, estratégico. Vencer todos os obstáculos mencionados demanda uma disposição de mudar a história de séculos. E, talvez, a diplomacia neoliberal a que se refere Cervo (2001), não seja suficiente. Aliás, as tendências são todas contrárias a uma concretização da América Latina. Se aproxima a consolidação da Alca (Acordo de Livre Comércio das Américas) e, com ele, a distinção da América Latina no continente será ainda mais difícil.

O que esse trabalho sugere, a partir dos casos do México e do Brasil, é que um dos maiores dificultadores de um projeto comum é justamente o nacionalismo dos países latino americanos. Se, por um lado esse nacionalismo pode ser uma oposição ao imperialismo, por outro, é uma barreira a uma percepção comum de problemas que, no fim das contas, são comuns.

\section{REFERÊNCIAS}

ALTMANN, Werner. México e Cuba: revolução, nacionalismo, política externa. São Leopoldo: Unisinos, 2002. 
ALMEIDA, Paulo Roberto de. O estudo das relações internacionais do Brasil. São Paulo: Unimarco, 1999.

BANDEIRA, Moniz. Estado nacional e política internacional na América Latina- o continente nas relações Argentina- Brasil (1930-1992). São Paulo: Ensaio, 1995.

. De Martí a Fidel: a Revolução Cubana e a América Latina. Rio de Janeiro: Civilização Brasileira, 1998.

BARBOSA, Rubens; CÉSAR, Luís Panelli. A Integração Sub-regional, Regional e Hemisférica: o Esforço Brasileiro. In: FONSECA JÚNIOR, Gelson; CASTRO, Sérgio Nabuco de (Org.). Temas de Política Externa Brasileira II. Rio de Janeiro: Paz e Terra, 1994. $2 \mathrm{v}$.

BOLÍVAR, Simón. Escritos políticos. Campinas: Unicamp, 1992.

BUENO, Clodoaldo; CERVO, Amado Luiz. História da política exterior do Brasil. 2. ed. Brasília: UNB, 2002. (Coleção o Brasil e o mundo).

CERVO, Amado Luiz. Relações Internacionais da América Latina. Brasília: IBRI, 2001.

CORRÊA, Anna Maria Martinez. A Revolução Mexicana (1910-1917). São Paulo: Brasiliense, 1983 (coleção Tudo é História - 62).

CORREAA, Luiz Felipe de Seixa. As Conferências de Cúpula Ibero- Americanas: um formato em busca de substância. In: FONSECA JR. Gelson; NABUCO DE CASTRO, Sergio (Org.): Temas de Política Externa Brasileira II. Brasília: Fundação Alexandre de Gusmão, 1994. , v. 1. p.147-165.

D’ARAÚJO, Maria Celina; CASTRO, Celso. Ernesto Geisel. Rio de Janeiro: FGV, 1998. DONGHI, Tulio Halperin. História da América Latina. Rio de Janeiro: Paz e Terra, 1997. EZCURRA, Andres Townsend. Patria Grande-pueblo, parlamento e integracion. Lima, Fondo Editorial del Congreso del Perú, 1991.

FERREIRA, Oliveiros. A América Latina dos señoritos. Integração e desintegração na América Latina. Revista Lua Nova, São Paulo, n.21, p.55-72, out. 1990.

GOES FILHO, Synesio Sampaio. Navegantes, bandeirantes e diplomatas: um ensaio sobre a formação das fronteiras no Brasil. São Paulo: Martins Fontes, 1999.

GONÇALVES, Willians da Silva; MYAMOTO, Shiguenoli. Os militares na política externa brasileira: 1964-1984. Estudos históricos, Rio de Janeiro, v. 6, n. 12, p. 211 246, 1993.

GREEN, Rosário. Brechas na negociação internacional do México. In: PLASTINO, Carlos Alberto; BOUZAS, Roberto (Org.). A América Latina e a crise internacional. Rio de Janeiro: Graal, 1985.

HAKIM, Peter. Brasil e México: duas maneiras de ser global. Política Externa, v.10, n. 4, p.94-108, mar/abr/maio, 2002.

KUNZLER, Jacob Paulo; MACIEL, Carlos. Mercosul e o mercado internacional: uma análise da economia mundial dividida em blocos regionais, com destaque para o Mercosul. Porto Alegre: Ortiz, 1994.

LAFER, Celso. A identidade internacional do Brasil e a politica externa brasileira: passado, presente e futuro. São Paulo: Perspectiva, 2004.

LAFER, Celso; PEÑA, Feliz. Argentina e Brasil no sistema das relações internacionais. São Paulo: Duas Cidades, 1973.

LIMA, Nestor dos Santos. La Imagen del Brasil en las cartas de Bolivia. Rio de Janeiro: Banco do Brasil, 1978. 
MAGNOLI, Demétrio. O corpo da pátria- imaginação geográfica e política externa no Brasil (1808-1912). São Paulo: Unesp/Moderna, 1997.

MAIOR, Luiz A. P. Souto. América Latina: o regionalismo continental revisitado. Revista Brasileira de Política Internacional, Brasília, ano 39, n. 2, p.117, 1996.

MATTOS, Carlos de Meira. Uma geopolítica pan-amazônica. Rio de Janeio: Biblex, 1980. MELLO, Flávia de Campos. Regionalismo e inserção internacional: continuidade e transformação da política externa brasileira nos anos 90. 2000. Tese (Doutorado) - FFLCH, Universidade de São Paulo, São Paulo.

MRE. Viagem do presidente João Goulart aos Estados Unidos da América e ao México. Brasília: Ministério das Relações Exteriores do Brasil, Seção de Publicações, 1962.

OLIVEIRA, Henrique Altemani de. A política externa brasileira: a ciência e a tecnologia nos esforços de industrialização. Brasília: Unb, 1994. (Cadernos de Relações Internacionais, n. 9).

PELLICER, Olga. Política externa mexicana: continuidade e incerteza em momentos de crise. In: PLASTINO, Carlos Alberto; BOUZAS, Roberto (Org.). A América Latina e a crise internacional. Rio de Janeiro: Graal, 1985.

SEITENFUS, Ricardo Antônio Silva. A cooperação argentino- brasileira: significado e perspectivas. Relações Internacionais e o Brasil. Revista Lua Nova, São Paulo, n.18, p. 107126, ago. 1989.

SERRANO, Huerta; GUADALUPE, María. Breve história das relações diplomáticas México-Brasil. Guia Documental. México: SER, 1994.

TRAVASSOS, Mário. Projeção Continental do Brasil. São Paulo: Companhia Editora Nacional, 1938.

VIZENTINI, Paulo Faguntes. A política externa do regime militar brasileiro: mulitlateralização, desenvolvimento e a construção de uma potência média (1964-1985). Porto Alegre: Ed. Da Universidade/UFRGS, 1998. 